\title{
Comparing drivers of social media marketing adoption by salespeople in Australia and the USA: a pilot study
}

\section{Iryna Pentina* and Ellen Bolman Pullins}

University of Toledo, 2801 W. Bancroft St., MS 103,

Toledo, Ohio 43606, USA

E-mail: ipentin@utnet.utoledo.edu

E-mail: Ellen.pullins@utoledo.edu

*Corresponding author

\section{John W. Wilkinson}

University of South Australia, GPO Box 2471, Adelaide SA 5001, Australia

E-mail: john.wilkinson@unisa.edu.au

\begin{abstract}
As social media increasingly penetrate the business world, it is important to identify reasons for salespeople to adopt social media marketing (SMM). This pilot study explores the influence of personal innovativeness, social influence, perceived usefulness and perceived ease of use in SMM adoption by salespeople in Australia and the USA. Findings do not support the key technology acceptance model (TAM) determinants of usefulness and ease of use as adoption drivers. Rather, SMM adoption in Australia is affected by social influence from competitors and supervisors, while personal innovativeness is the major driver of SMM adoption in the USA. Both social influence and the extent of SMM adoption affect SMM continuance intentions in the USA, but only the extent of SMM adoption influences such intentions in Australia. The paper also discusses the implications of these findings for sales managers.
\end{abstract}

Keywords: social media; marketing; sales; cross-cultural; USA; Australia.

Reference to this paper should be made as follows: Pentina, I., Pullins, E.B. and Wilkinson, J.W. (2014) 'Comparing drivers of social media marketing adoption by salespeople in Australia and the USA: a pilot study', Int. J. Information Systems and Management, Vol. 1, Nos. 1/2, pp.146-165.

Biographical notes: Iryna Pentina is an Assistant Professor at the University of Toledo. Her research interests include social and interactive marketing, applicability of marketing theory to online sales, internet retailing and virtual communities. She is a recipient of the Fulbright Scholar award and has published papers in European Journal of Marketing, Journal of Retailing, International Journal of Electronic Commerce, Journal of Electronic Commerce Research, European Journal of Innovation Management, Journal of Consumer Behaviour and others. 
Ellen Bolman Pullins is the Director of the Edward H. Schmidt School of Professional Sales and the Schmidt Research Professor. She received her $\mathrm{PhD}$ in Marketing from the Ohio State University (1996). She teaches and researches in sales and related areas. Her research has appeared in Journal of Marketing Research, Journal of Academy of Marketing Science, Journal of Personal Selling and Sales Management, Industrial Marketing Management, etc. She is active in the American Marketing Association Sales SIG, Global Sales Science Institute, the National Conference in Sales Management and a number of other national and international organisations in the professional sales area.

John W. Wilkinson is the Associate Head of the School of Marketing, and Research Associate at Ehrenberg-Bass Institute for Marketing Science, University of South Australia. He gained his PhD degree from the University of South Australia, where he currently undertakes research and teaching in sales and distribution management. He has published in several international journals, and co-authored or contributed to three textbooks in marketing and sales management.

\section{Introduction}

Social media now constitute the fastest-growing marketing channel, with US expenditures expected to grow $21 \%$ annually to reach US\$9.8 billion by 2016 (BIA/Kelsey, 2012). In contrast to paid online advertising (banner, text and search), social media marketing (SMM) involves initiating viral consumer-to-consumer communication by creating company/brand fan pages, and managing promotions and public relations within most popular social networks, such as Facebook, YouTube and Twitter. Applications such as product sharing and voting, collaborative design, and product launch announcements may provide relevance, immediacy and convenience to customers, as well as publicity and brand name recognition to firms (Evans, 2009).

SMM offers benefits to salespeople due to moderate costs and the flexibility with which a salesperson can adapt social networks for marketing and selling purposes. While such benefits are strongly supported by experts, the decision by salespeople to adopt this new technology is not automatic. Challenges include lack of demonstrable results and difficulties in developing effective measurement metrics (Internet Advertising Bureau, 2010). These challenges, and the risk of potential negative 'viral spread' on companies' reputations, pose obstacles to SMM adoption. Despite this, increasing numbers of salespeople are making social networks an integral part of their marketing strategy. Understanding the drivers of SMM acceptance by salespeople may help provide practical advice to firms regarding sales planning and budget allocation, and assist academics in further development of sales theory in the area of SMM.

The technology acceptance model (TAM) postulates that an organisational decision to adopt a new technology is mainly based on perceptions of ease of use and usefulness (Davis, 1989). However, use of social media does not require considerable technological skills, relying instead on existing marketing, public relations and customer service skills. Moreover, the usefulness of SMM is currently difficult to assess due to a lack of measurable marketing and sales metrics. Therefore, other factors may influence the decision to adopt SMM. 
The objective of this paper is to investigate the roles of TAM-based antecedents and other personal and social factors in salespeople's adoption and continued use of SMM. In particular, the authors propose and test the impact of social influence (SI) (by colleagues, supervisors, competitors and customers) and personal innovativeness (PI) in SMM acceptance by salespeople, and compare their effect in the Australian and US contexts. The remainder of the paper is organised as follows: first, theoretical propositions are developed, and data collection and analysis methods are described; next, the findings are discussed, and conclusions, managerial implications and research recommendations are provided.

\section{SMM and personal selling}

Recent developments in Web 2.0 and $3 \mathrm{G} / 4 \mathrm{G}$ technologies have created a shift in business-to-customer relationships and information control. Customers are no longer passive 'receivers' of sales messages. Instead, they initiate conversations with and provide feedback to firms, as well as creating and sharing content among themselves. Social media allow users to create and share personal profiles, establish and develop connections, and provide or acquire information in an interactive manner (Boyd and Ellison, 2008). Open access to other members' contacts provides opportunities to control the process of sales communication by spreading messages about products, brands and sales agents that can be beneficial or detrimental to any firm.

SMM practices include operating a company's fan page, managing promotions and public relations, conducting market research, providing customer support, and encouraging customer reviews and discussions (McCorvey, 2010). Academics and practitioners agree that the key to success with SMM is the ability to engage followers. For example, WetSeal, an online clothes store, increased sales and order values by $10 \%$ by launching a community section of its website in which fans can design their own ensembles and publish those for review. Zappos, an online shoe store, uses Twitter to address customer service issues and to reinforce its reputation by encouraging employees to participate in Twitter (Brennan and Schafer, 2010).

While SMM successes have been publicised, and benefits to salespeople of using social media have been discussed extensively, the decision to adopt SMM as a sales tool is not automatic (Drossos et al., 2011). According to the Internet Advertising Bureau (2010), challenges include lack of demonstrable return on investment in SMM, and absence of reliable reporting metrics. Another study identified inability to measure SMM return on investment as a major barrier for $43 \%$ of responding firms (Marketing Sherpa, 2009). Higher numbers of viewers, visitors, friends or followers do not necessarily translate to higher conversions, order values or sales. Given their viral nature, social media may be more effective in enhancing brand awareness or reputation than generating sales leads (Barnes and Hair, 2009). However, SMM is only one component of integrated marketing communication, and it is difficult to determine its contribution compared to other forms of promotion.

In view of the lack of demonstrable success and adequate measurement metrics, other factors may be responsible for salespeople's adoption of SMM technology. This study explores the roles of SI and PI, as well as traditional TAM drivers of usefulness and ease of use, in affecting salespeople's SMM adoption in Australia and the USA. 


\section{Theoretical development}

The TAM predicts intention to adopt a new technology by organisational users/decisionmakers (Davis et al., 1989). Although initially developed to predict user acceptance of computer technology within the workplace, it has been considered a suitable theoretical basis for understanding use and acceptance of various internet-based technologies in varied contexts (Gefen et al., 2003). For example, TAM has been widely applied and empirically supported to predict the adoption of information technology (Taylor and Todd, 1995), computers (Davis et al., 1989), and technology-based self-service (Dabholkar and Bagozzi, 2002). The adoption of such diverse technologies as mobile commerce (Wu and Wang, 2005), financial services (McKechnie et al., 2006), multimedia instruction (Saadé et al., 2007), and online games (Hsu and Lu, 2004) has been successfully predicted by TAM. TAM has also been applied to such personal communication technologies as e-mail (Straub et al., 1997), cellular phones (Kwon and Chidambaram, 2000), and instant messaging (Lu et al., 2009). Finally, TAM has been successfully applied in a range of online marketing contexts, including e-business (Parker and Castleman, 2009), mobile marketing (Sultan et al., 2009) and online retailing adoption (O'Cass and Fenech, 2003).

SMM conforms to the Miriam-Webster Dictionary definition of technology as an application of the existing knowledge, tools and techniques to the practical aims in order to make life easier and work more productive. In line with this conceptualisation, SMM is an internet (and mobile)-based technology that utilises digitally mediated communication techniques and marketing knowledge to deliver marketing and sales messages, achieve sales objectives, and make the work of marketers more productive. Therefore, it is deemed appropriate to apply TAM to the context of SMM adoption.

Derived from the social-psychology theory of reasoned action (Fishbein and Ajzen, 1975) and theory of planned behaviour (Ajzen, 1991), TAM posits that a user's intention to use a technology is determined by two beliefs: perceived usefulness (PU) and perceived ease of use (PEU). PU is the extent to which a person believes use of the technology will enhance job performance, and PEU is the belief that use of the technology will be effortless. PEU is also posited to positively influence PU (Venkatesh and Davis, 2000). In various contexts, PU has been robust in predicting user acceptance, although PEU has shown a less consistent influence (Venkatesh and Davis, 2000). Both factors have been identified as antecedents of salespersons' adoption of sales automation technology (Schillewaert et al., 2005). The following hypotheses are based on the above issues:

H1a Salespeople who perceive greater usefulness of SMM are more likely to adopt SMM.

H1b Salespeople who perceive greater ease of SMM use are more likely to adopt SMM.

H1c PEU has an indirect positive effect (via PU) on salespeople's adoption of SMM.

Receptivity toward adopting information technology has been emphasised in defining success of the technology (Agarwal and Prasad, 1998), while a salesperson's innovativeness has been shown to determine willingness to use technology for tasks requiring new selling routines (Churchill et al., 1993). In the area of information technology, sales experts identify a natural resistance by salespeople that should be 
overcome to accelerate adoption of technology (Campbell, 1998). It also has been found that PI is a potent driver of the adoption of sales automation technology (Schillewaert et al., 2005). Therefore, a salesperson's PI, as an emotional, cognitive and conative predisposition toward adopting new technologies, appears likely to be an important factor in SMM adoption. Therefore, it is hypothesised that:

H2 Salespeople with greater PI (emotional, cognitive and conative) are more likely to adopt SMM.

Prior studies have attempted to extend TAM to include other factors that may influence technology adoption. A frequently proposed factor is SI, defined as a user's perception that important people believe the user should adopt the technology (Venkatesh and Davis, 2000). In several studies (Malhotra and Galletta, 1999; Venkatesh and Davis, 2000), SI is posited to affect adoption indirectly, through PU, based on the concept of internalisation, in which the user incorporates an important referent's belief into his or her own belief structure (Kelman, 1958). The internalisation component of SI has been compared to French and Raven's (1959) expert power, in which the user's perception of the usefulness of technology increases based on persuasive social information.

In the SMM context, due to a lack of measurement metrics, SI appears to affect adoption directly through the mechanism of compliance (French and Raven, 1959; Kelman, 1958). Compliance occurs when the user believes a social referent is able to reward or punish adoption behaviour, and is influenced by the referent's opinion even without acceptance or internalisation of that opinion. Empirically, while Davis et al. (1989) found that SI does not have a significant effect on intentions to use new information systems, Taylor and Todd (1995) found a significant direct effect of SI on intention. Additionally, SI has been shown to affect the adoption and use of new media (Webster and Trevino, 1995) and adoption of new technology in education (Robinson, 2006). In a study of adoption of broker workstations, Lukas and Spitler (1999) found that SI is a stronger predictor of intended use than PU or PEU. Venkatesh and Davis (2000) confirmed both direct and mediated (by PU) effects of SI on intention to adopt IT systems. In the sales context, SI from supervisors, peers and competitors were found to directly affect sales automation technology adoption (Schillewaert et al., 2005). Based on the above, it is hypothesised that:

H3 Salespeople who experience SI to adopt SMM are more likely to adopt SMM.

The role of SI in adopting a new technology maybe influenced by the degree of experience with the technology (Venkatesh and Davis, 2000). Hartwick and Barki (1994) found that SI influence became minor several months after an information technology implementation, and Venkatesh and Davis (2000) reported that the influence of social factors was significantly moderated by experience, decreasing several months after a new business technology implementation. It is therefore theorised that in the USA, where SMM technology has long been in use and is widely implemented, and SMM strengths and challenges are likely to be well understood, the role of SI in affecting adoption is likely to be lower than in countries in which data are less available (and opinions of experts, peers or supervisors are thus more influential).

Salespeople may feel compelled to use SMM because customers use online social networks and expect communication through those media. Therefore, salespeople may feel pressured to create their own fan pages even before developing SMM strategies or being convinced of the effectiveness of the technology. Peer usage and encouragement by 
superiors also have been shown to encourage adoption and learning about system benefits (Bandura, 1977). Due to a lack of metrics and uncertainty regarding the length of SMM influence on sales results, the authors theorise that SI will be a major influence on intentions to adopt in contexts in which assessment and comparability of results are less available (e.g., Australia), but not in contexts (e.g., USA) in which objective information on effectiveness is available (e.g., from professional associations). Therefore, it is hypothesised that:

H4 Salespeople who experience SI to adopt SMM in Australia are more likely to adopt SMM than salespeople who experience SI to adopt SMM in the USA.

Once a salesperson has established his or her social media presence, compliance with customer and supervisor expectations may be an important factor driving continuation of SMM use. Thus, salespeople who have had friends and fans following them on the social network for a long time may feel obligated to continue using SMM to avoid disappointments and negative repercussions. Similarly, if extrinsic rewards and/or recognition for SMM use are established by supervisors, these may provide an important incentive for continued use of SMM. The threat of losing competitive advantage (Abrahamson and Rosenkopf, 1993) exemplifies the SI of competitors that could persuade salespeople to continue using social media for sales purposes. Finally, the level of peer adoption that can provide access to expertise and mentoring also should have an impact on SMM continuance intentions (Fine and Bolman Pullins, 1998). Therefore, it is hypothesised that:

H5 Salespeople who experience SI to continue using SMM are more likely to continue using SMM.

Figure 1 Proposed conceptual model

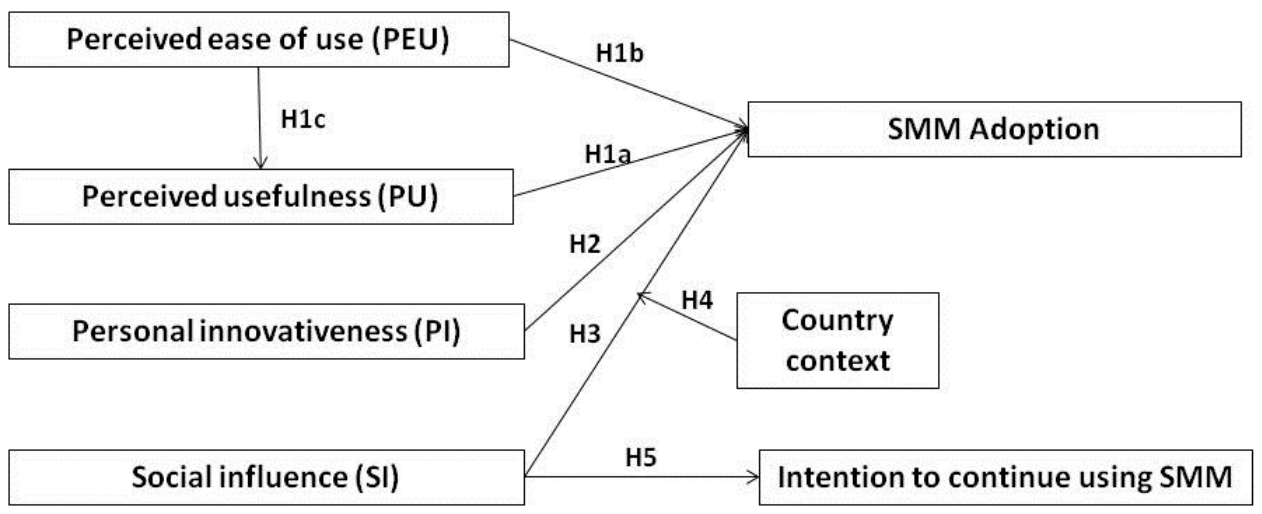

\section{Method}

\subsection{Procedure}

Utilising commercial distribution lists, salespeople in Australia and the USA were requested to complete an online survey about their experiences with, and plans for 
adopting and continuing to use, SMM (Appendix). The survey contained demographic and psychographic questions about the respondent's position and company, as well as questions relating to reasons for adopting SMM and measuring PI and SIs. Those questions were followed by TAM-related questions adapted to reflect the differences between those using SMM and those considering its adoption. The surveys were available for one month, and an incentive was offered in the form of a free report of the findings of the investigation.

\subsection{Sample}

In total, 105 responses were obtained (54 from the USS and 51 from Australia), representing a response rate of $6 \%-7 \%$. Given the pioneering nature of this pilot study, the sample size was deemed acceptable for the purpose of detecting the phenomena of interest (although not for the purposes of predicting or generalising). Australian respondents represented a wide variety of industries (Table 1), including businessto-business and consumer brand manufacturing, consumer and business services, distribution, and retailing, with $66 \%$ reporting annual revenues of greater than $\$ 25$ million. All US respondents represented consumer brand manufacturing companies with $81 \%$ of companies reporting annual revenue between $\$ 5$ million and $\$ 25$ million. A great majority $(74 \%)$ of the respondents held decision-making positions of sales manager or owner, upper-, or middle-manager in their companies, which made them appropriate subjects for testing TAM. About $83 \%$ of respondents were using SMM, and $96 \%$ had personal accounts in various social media.

Table 1 Characteristics of the sample

\begin{tabular}{|c|c|c|c|}
\hline & Total, \% & $U S A, \%$ & Australia, \% \\
\hline \multicolumn{4}{|l|}{ Primary business of firm } \\
\hline Consumer brand manufacturer & 58 & 100 & 9 \\
\hline B2B manufacturer & 14 & & 30 \\
\hline Business service provider & 6 & & 10 \\
\hline Distributor & 4 & & 7 \\
\hline Consumer service provider & 3 & & 7 \\
\hline Retailer & 3 & & 14 \\
\hline Other & 12 & & 25 \\
\hline \multicolumn{4}{|l|}{ Annual revenue of firm } \\
\hline Below $\$ 5$ million & 9 & 8 & 10 \\
\hline$\$ 5$ to $\$ 10$ million & 24 & 39 & 10 \\
\hline$\$ 10.01$ to $\$ 25$ million & 27 & 42 & 14 \\
\hline$\$ 25$ to $\$ 50$ million & 16 & 12 & 21 \\
\hline More than $\$ 50$ million & 24 & & 45 \\
\hline \multicolumn{4}{|l|}{ Position of respondent } \\
\hline Salesperson & 26 & 44 & 3 \\
\hline Sales manager & 30 & 23 & 39 \\
\hline Other sales-related position & 44 & 33 & 58 \\
\hline
\end{tabular}




\subsection{Measures}

The TAM scales for PU and PEU were adopted from Venkatesh and Davis (2000), and the SI, PI, SMM Adoption, and SMM Continuance Intention scales were adopted from Schillewaert et al. (2005). The survey was adapted to reflect the differences between SMM adopters and non-adopters. The question regarding experience with SMM, 'When did you start using social media marketing?' was only offered to SMM adopters. The version for non-adopters contained the question, 'When did you learn about social media marketing?' Additional questions related to reasons for SMM adoption and its benefits, as well as which social media sites were considered for SMM use or were currently being used (see Appendix). Descriptive statistics of the main constructs are provided separately for US and Australian sub-samples in Table 2.

Table 2 Descriptive statistics for main constructs

\begin{tabular}{lccccc}
\hline Construct & $\begin{array}{c}\text { \# of } \\
\text { items }\end{array}$ & Range & Mean & Variance & $\begin{array}{c}\text { Cronbach's } \\
\text { alpha }\end{array}$ \\
\hline Perceived ease of use whole sample & 4 & $6.75(1.25$ to 8$)$ & 4.96 & 3.07 & 0.952 \\
USA & 4 & $5(3$ to 8$)$ & 5.8 & 2.07 & 0.96 \\
Australia & 4 & $6.75(1.25$ to 8$)$ & 4.09 & 2.66 & 0.938 \\
\hline Perceived usefulness whole sample & 4 & $6(2$ to 8$)$ & 4.96 & 3.33 & 0.893 \\
USA & 4 & $6(2$ to 8$)$ & 5.26 & 3.96 & 0.785 \\
Australia & 4 & $6(2$ to 8$)$ & 4.67 & 2.62 & 0.927 \\
\hline Personal innovativeness & 3 & $6(1$ to 7$)$ & 4.65 & 1.53 & 0.715 \\
USA & 3 & $6(1$ to 7$)$ & 4.47 & 1.6 & 0.778 \\
Australia & 3 & $4.67(2.33$ to 7$)$ & 4.82 & 1.46 & 0.759 \\
\hline Social influence whole sample & 14 & $6.57(1.43$ to 8$)$ & 4.28 & 3.14 & 0.942 \\
USA & 14 & $5.86(2.14$ to 8$)$ & 5.04 & 3.45 & 0.952 \\
Australia & 14 & $4.07(1.43$ to 5.5$)$ & 3.43 & 1.5 & 0.872 \\
\hline Intention to use whole sample & 4 & $6(1$ to 7$)$ & 3.6 & 2.4 & 0.812 \\
USA & 4 & $6(1$ to 7$)$ & 4.04 & 2.28 & 0.861 \\
Australia & 4 & $6(1$ to 7$)$ & 3.17 & 2.21 & 0.843 \\
\hline Intention to continue whole sample & 3 & $9(12$ to 21$)$ & 17.15 & 7.05 & 0.845 \\
USA & 3 & $9(12$ to 21$)$ & 16.75 & 6.71 & 0.822 \\
Australia & 3 & $8(13$ to 21$)$ & 17.6 & 7.33 & 0.923 \\
\hline
\end{tabular}

\section{Results}

The Australian and US sub-samples were compared with respect to respondent position in the firm and major company characteristics. A significant difference was found in the annual revenue of the respondents' firms: $45 \%$ of Australian respondents worked for firms with annual revenues of US\$50 million and higher, while $54 \%$ of US respondents worked for firms with annual revenues of US\$10-50 million $\left(\chi^{2}=21.1, \mathrm{p}<0.001\right)$. Additionally, US respondents mainly represented consumer brand manufacturing industry, while Australian respondents were widely distributed among B2B manufacturing, retailing, and services, and consumer brand manufacturing. As expected, 
a significant difference was found in the years of SMM experience, with $62 \%$ of Australian respondents starting SMM utilisation less than two years ago and $45 \%$ of US respondents more than three years ago $\left(\chi^{2}=14.7, p=0.005\right)$. Based on these differences, the analysis proceeded separately for each sub-sample.

Contrary to expectations, none of the TAM-postulated determinants of technology adoption were significant drivers of SMM adoption for either the US $\left(\beta_{\mathrm{EOU}}=0.3 ; p=0.1\right.$; $\left.\beta_{\mathrm{PU}}=0.01 ; \mathrm{p}=0.95\right)$ or the Australian $\left(\beta_{\mathrm{EOU}}=0.025 ; \mathrm{p}=0.94 ; \beta_{\mathrm{PU}}=0.23 ; \mathrm{p}=0.73\right)$ sub-samples. Therefore, mediation analysis was deemed unnecessary and Hypotheses 1a, $1 \mathrm{~b}$ and $1 \mathrm{c}$ were not supported. The TAM model components were excluded from further analysis.

Hypotheses 2, 3 and 4 were tested using linear regressions with Adoption as the dependent variable and PI and SI as independent variables in each sub-sample [Table 3(a)]. H2 was partially supported, showing a significant role of PI in influencing SMM adoption for US respondents only $\left(\beta_{\mathrm{PI}}=0.599 ; \mathrm{p}=0.002\right)$. In partial support of $\mathrm{H3}$ and full support of H4, differential results were obtained for the role of SI in SMM adoption: for US respondents, SI does not appear to drive initial adoption $\left(\beta_{\mathrm{SI}}=-0.198\right.$; $\mathrm{p}=0.265)$, as opposed to Australian respondents $\left(\beta_{\mathrm{SI}}=0.655 ; \mathrm{p}<0.001\right)$. Further analysis to identify types of SI most important for SMM adoption in Australia showed that competitors $\left(\beta_{\text {SICompetitors }}=0.327 ; p=0.063\right)$ and supervisors $\left(\beta_{\text {SISupervisor }}=0.477\right.$; $\mathrm{p}=0.008$ ), but not customers and colleagues, play a role in salespersons' decision to use SMM [Table 3(b)].

Table 3(a) Personal and social drivers of SMM adoption by sales personnel

\begin{tabular}{|c|c|c|c|c|c|c|}
\hline \multirow{3}{*}{ Independent variables } & \multicolumn{6}{|c|}{ Dependent variable: SMM adoption } \\
\hline & \multicolumn{3}{|c|}{ USA } & \multicolumn{3}{|c|}{ Australia } \\
\hline & Beta & $t$ & $p$ & Beta & $t$ & $p$ \\
\hline (Constant) & & 1.745 & .092 & & -.603 & .552 \\
\hline Personal innovativeness & .599 & 3.445 & .002 & .182 & 1.235 & .228 \\
\hline Social influences & -.198 & -1.138 & .265 & .655 & 4.457 & .000 \\
\hline $\mathrm{R}$ square & & .306 & & & .46 & \\
\hline Adjusted R square & & .255 & & & .417 & \\
\hline $\mathrm{F}$ & 5.958 & Sig. & .007 & 10.658 & Sig. & .000 \\
\hline
\end{tabular}

Table 3(b) Post-hoc analysis of social drivers of SMM adoption in Australia

\begin{tabular}{lccc}
\hline Independent variables & Beta & $t$ & $p$ \\
\hline (Constant) & & -.315 & .756 \\
Personal innovativeness & .154 & 1.013 & .322 \\
Social influences (competitors) & .327 & 1.961 & .063 \\
Social influences (supervisor) & .477 & 2.928 & .008 \\
Social influences (customers) & .079 & .457 & .652 \\
Social influences (colleagues) & .036 & .216 & .831 \\
R square & & .516 & \\
Adjusted R square & & .406 & \\
F & 4.696 & Sig. & .005 \\
\hline
\end{tabular}


Finally, Hypothesis 5 was tested using linear regressions with Intention to Continue SMM Use as the dependent variable and PI, SI and Adoption as independent variables in each sub-sample. H5 was partially supported, showing differences in the continuance intentions of each sub-sample: SI was only significant in the US sample $\left(\beta_{\mathrm{SI}}=0.316\right.$; $\mathrm{p}=0.009)$, along with the adoption extent $\left(\beta_{\mathrm{A}}=0.894 ; \mathrm{p}<0.001\right)$ in predicting SMM continuance intentions [Table 4(a)]. For the Australian sub-sample, the only (marginally) significant driver of continuance intentions was the SMM adoption extent $\left(\beta_{\mathrm{A}}=0.439\right.$; $\mathrm{p}=0.067$ ). Further analysis to identify the types of SI most important for SMM continuance in the USA showed that only the combined customer-competitor influence $\left(\beta_{\text {SICC }}=0.263 ; p=0.03\right)$ and that of supervisors $\left(\beta_{\text {SISupervisor }}=0.448 ; p=0.001\right)$, but not of colleagues, play a role in salespersons' decisions to continue using SMM [Table 4(b)].

Table 4(a) Drivers of intention to continue using SMM by sales personnel

\begin{tabular}{|c|c|c|c|c|c|c|}
\hline \multirow{3}{*}{ Independent variables } & \multicolumn{6}{|c|}{ Dependent variable: CMM continuance } \\
\hline & \multicolumn{3}{|c|}{$U S A$} & \multicolumn{3}{|c|}{ Australia } \\
\hline & Beta & $t$ & $p$ & Beta & $t$ & $p$ \\
\hline (Constant) & & -2.143 & .042 & & 2.164 & .041 \\
\hline Personal innovativeness & -.188 & -1.432 & .164 & .011 & .061 & .952 \\
\hline Adoption & .899 & 7.424 & .000 & .439 & 1.919 & .067 \\
\hline Social influences & .316 & 2.822 & .009 & .146 & .648 & .523 \\
\hline $\mathrm{R}$ square & & .738 & & & .298 & \\
\hline Adjusted R square & & .707 & & & .210 & \\
\hline $\mathrm{F}$ & 24.364 & Sig. & .000 & 3.397 & Sig. & .034 \\
\hline
\end{tabular}

Table 4(b) Post-hoc analysis of social drivers of SMM continuance in the USA

\begin{tabular}{lccc}
\hline Independent variables & Beta & $t$ & $p$ \\
\hline (Constant) & & -2.378 & .026 \\
Personal innovativeness & -.188 & -1.778 & .094 \\
Adoption & .955 & 9.371 & .000 \\
Social influences (competitors and customers) & .263 & 2.314 & .030 \\
Social influences (supervisor) & .448 & 3.912 & .001 \\
Social influences (colleagues) & -.185 & -1.633 & .116 \\
R square & & .834 & \\
Adjusted R square & & .799 & \\
F & 24.068 & Sig. & .000 \\
\hline
\end{tabular}

\section{Discussion}

Findings suggest that TAM may not be an optimal theoretical framework for understanding salespersons' adoption of SMM for professional purposes. The fact that neither PU nor PEU affected SMM adoption in Australia or the USA underscores the need to explore other factors facilitating adoption in such specific contexts as social media. In the absence of usefulness criteria and bottom-line results, or particular SMM 
strategies, and with the overwhelming (potentially false) perception of easiness to use SMM, traditional determinants of technology adoption may have less salience in explaining the SMM phenomenon.

Indeed, our pilot study suggests that both PI of a salesperson (in the USA) and SI (in Australia) are important antecedents of SMM adoption for sales purposes. While our tentative explanation of different drivers of SMM adoption in two countries is the difference in levels of experience with the technology in these countries, further studies with larger samples need to explore other potential moderators of these relationships.

An interesting finding of this pilot study is the changing role for SI in the USA: while SI plays no role in a salesperson's initial adoption of SMM, it significantly affects the intention to continue using SMM for professional purposes. A potential explanation may be the pressure of expectations arising from both external (customers and competitors) as well as internal (supervisor) social forces once the salesperson embarks on the social media 'bandwagon'. However, this does not explain why SI loses its importance for continuance intentions in Australia after having played an important role in initial SMM adoption. Thus, longitudinal research that would take into account the individual salesperson's experience of utilising the technology, as well as the development of public and professional opinions about the technology, seems appropriate.

The identified role of PI, as an individual salesperson's predisposition to adopt a new technology, supports the stream of sales research emphasising personal characteristics as important drivers of behaviour. A lack of influence of PI on SMM adoption in Australia may tentatively suggest differences in culture (e.g., in the dimension of individualism) or business reality (e.g., entrepreneurship). Further research in more comparable companies would clarify the role of PI in salespeople's technology adoption.

\section{Conclusions and limitations}

This pioneering study contributes to the existing literature on new technology adoption by elucidating the potential role of context in the explanatory power of the TAM. The context of SMM technology in sales is characterised by lack of measures of its usefulness, as well as by misconceptions of its ease of use, rendering less salience to the traditional TAM-related technology adoption determinants. In the absence of technologyrelated antecedents, personal and social factors dominate the process of adoption and continuance intentions of SMM for sales. Our intriguing finding of different antecedents of SMM adoption in the USA and Australia can imply cultural, as well as technology implementation-related (e.g., level of SMM penetration and industry experience with SMM) explanations. Clearly, more cross-cultural research is needed to better understand the identified differences.

Although the results of this study provide an important contribution to technology adoption and social media literature and practice, they should be generalised with caution to larger contexts and populations. Relatively small sample sizes of the US and Australian respondents and lack of their match in terms if company size and type warrant additional cross-cultural and more representative studies to validate or challenge the reported findings. 
Still, the findings of this paper open up some interesting avenues for future research. First, cross-cultural differences in SMM adoption and use emerge and warrant further exploration, especially given the global nature of many social media. Second, the area of SI needs further investigation. It is apparent that different types of SI may manifest differently in different contexts and SMM adoption stages, and we need to understand potential moderator effects of these manifestations. Finally, the fact that PI was only relevant in the US SMM adoption may raise some interesting questions. Are more innovative individuals being hired in the USA as sales continue to become more strategic, complex and co-creational? Or does the role of innovativeness reflect cultural differences? We believe that the light shed on the need to explore these questions is valuable in and of itself and that this pilot study contributes to both our overall understanding of the SMM adoption phenomenon, and to introducing these new questions.

\section{References}

Abrahamson, E. and Rosenkopf, L. (1993) 'Institutional and competitive bandwagons: using mathematical modeling as a tool to explore innovation diffusion', Academy of Management Review, Vol. 18, No. 3, pp.487-517.

Agarwal, R. and Prasad, J. (1998) 'The antecedents and consequences of user perceptions in information technology adoption', Decision Support Systems, Vol. 22, No. 15, pp.15-29.

Ajzen, I. (1991) 'The theory of planned behavior', Organizational Behavior and Human Decision Processes, Vol. 50, No. 2, pp.11-39.

Bandura, A. (1977) Social Learning Theory, Prentice Hall, Englewood Cliffs, NY.

Barnes, S.B. and Hair, N.F. (2009) 'From banners to YouTube: using the rearview mirror to look at the future of internet advertising', International Journal of Internet Marketing and Advertising, Vol. 5, No. 3, pp.223-239.

BIA/Kelsey (2012) BIA/Kelsey Forecasts U.S. Social Media ad Spending to Reach $\$ 9.8$ Billion by 2016 [online] http://www.biakelsey.com/Research-and-Forecasts/Forecasts/ (accessed 25 June 2012).

Boyd, D.M. and Ellison, N.B. (2008) 'Social network sites: definition, history, and scholarship', Journal of Computer-Mediated Communication, Vol. 13, No. 1, pp.210-230.

Brennan, B. and Schafer, L. (2010) Branded!: How Retailers Engage Consumers with Social Media and Mobility, Wiley Publishing, New Jersey.

Campbell, T. (1998) 'Beating the sales force technophobia', Sales and Marketing Management, Vol. 150, No. 13, pp.68-72.

Churchill, G.A., Ford, N.M. and Walker, O.C. (1993) Sales Force Management: Planning, Implementation and Control, 4th ed., Irwin, Homewood, IL.

Dabholkar, P.A. and Bagozzi, R. (2002) 'An attitudinal model of technology-based self-service: moderating effects of consumer traits and situational factors', Journal of the Academy of Marketing Science, Vol. 30, No. 3, pp.184-202.

Davis, F.D. (1989) 'Perceived usefulness, perceived ease of use, and user acceptance of information technology', MIS Quarterly, Vol. 13, No. 3, pp.319-339. 
Davis, F.D., Bagozzi, R. and Warshaw, P. (1989) 'User acceptance of computer technology: a comparison of two theoretical models', Management Science, Vol. 35, No. 8, pp.982-1004.

Drossos, D.A., Fouskas, K.G., Kokkinaki, F. and Papakyriakopoulos, D. (2011) 'Advertising on the internet: perceptions of advertising agencies and marketing managers', International Journal of Internet Marketing and Advertising, Vol. 6, No. 3, pp.244-264.

Evans, D. (2009) 'Social media is tailor-made for SMBs', Clicz, 28 October [online] http://www.clicz.com/3635468 (accessed 10 January 2010).

Fine, L.M. and Bolman Pullins, E. (1998) 'Peer mentoring in the industrial sales force: an exploratory investigation of men and women in developmental relationships', Journal of Personal Selling and Sales Management, Vol. 18, No. 4, pp.89-103.

Fishbein, M. and Ajzen, I. (1975) Belief, Attitude, Intention, and Behavior: An Introduction to Theory and Research, Addison-Wesley, Reading, MA.

French, J.R.P. and Raven, B. (1959) 'The bases of social power', in D. Cartwright (Ed.): Studies in Social Power, pp.150-167, Institute for Social Research, Ann Arbor, MI.

Gefen, D., Karahanna, E. and Straub, D. (2003) 'Trust and TAM in online shopping: an integrated model', MIS Quarterly, Vol. 27, No. 1, pp.51-90.

Hartwick, J. and Barki, H. (1994) 'Explaining the role of user participation in information system use', Management Science, Vol. 40, No. 4, pp.440-465.

Hsu, C.L. and Lu, H.P. (2004) 'Why do people play on-line games? An extended TAM with social influences and flow experience', Information \& Management, Vol. 41, No. 7, pp.853-868.

Internet Advertising Bureau (2010) Social Media Budgets Set for Increase [online] http://www.iabuk.net/en/1/socialmediabudgetssetforincrease020210.mxs (accessed 14 February 2010).

Kelman, H.C. (1958) 'Compliance, identification, and internalization: three processes of attitude change', Journal of Conflict Resolution, Vol. 2, No. 1, pp.51-60.

Kwon, H.S. and Chidambaram, L. (2000) 'A test of the technology acceptance model: the case of cellular telephone adoption', in System Sciences, 2000. Proceedings of the 33rd Annual Hawaii International Conference on, 7p., IEEE.

Lu, Y., Zhou, T. and Wang, B. (2009) 'Exploring Chinese users' acceptance of instant messaging using the theory of planned behavior, the technology acceptance model, and the flow theory', Computers in Human Behavior, Vol. 25, No. 1, pp.29-39.

Lukas, H. and Spitler, V.K. (1999) 'Technology use and performance: a field study of broker workstations', Decision Sciences, Vol. 30, No. 2, pp.291-311.

Malhotra, Y. and Galletta, D.F. (1999) 'Extending the technology acceptance model to account for social influence: theoretical bases and empirical validation', in System Sciences, 1999. Proceedings of the 32nd Annual Hawaii International Conference on, 14p., IEEE.

Marketing Sherpa (2009) Social Media Marketing and PR: Benchmarks and Best Practices [online] http://www.marketingsherpa.com/exs/SocialMM09excerpt.pdf (accessed 14 June 2012). 
McCorvey, J.J. (2010) 'How to use social networking sites to drive business', Inc.com [online] http://www.inc.com/guides/using-social-networking-sites.html (accessed 14 June 2012).

McKechnie, S., Winklhofer, H. and Ennew, C. (2006) 'Applying the technology acceptance model to the online retailing of financial services', International Journal of Retail \& Distribution Management, Vol. 34, Nos. 4/5, pp.388-410.

O'Cass, A. and Fenech, T. (2003) 'Webretailing adoption: exploring the nature of internet users' web retailing behaviour', Journal of Retailing and Consumer Services, Vol. 10, No. 2 , pp.81-94.

Parker, C.M. and Castleman, T. (2009) 'Small firm e-business adoption: a critical analysis of theory', Journal of Enterprise Information Management, Vol. 22, Nos. 1/2, pp.167-182.

Robinson, L. (2006) 'Moving beyond adoption: exploring the determinants of student intention to use technology', Marketing Education Review, Vol. 16, No. 2, pp.79-88.

Saadé, R.G., Nebebe, F. and Tan, W. (2007) 'Viability of the 'technology acceptance model' in multimedia learning environments: a comparative study', Interdisciplinary Journal of Knowledge and Learning Objects, Vol. 3, No. 2, pp.175-184.

Schillewaert, N., Ahearne, M.J., Frambach, R.T. and Moenaert, R.K. (2005) 'The adoption of information technology in the sales force', Industrial Marketing Management, Vol. 34, No. 4, pp.323-336.

Straub, D., Keil, M. and Brenner, W. (1997) 'Testing the technology acceptance model across cultures: a three country study', Information \& Management, Vol. 33, No. 1, pp.1-11.

Sultan, F., Rohm, A.J. and Gao, T. (2009) 'Factors influencing consumer acceptance of mobile marketing: a two-country study of youth markets', Journal of Interactive Marketing, Vol. 23, No. 4, pp.308-320.

Taylor, S. and Todd, P. (1995) 'Understanding information technology usage: a test of competing models', Information Systems Research, Vol. 6, No. 2, pp.144-176.

Venkatesh, V. and Davis, F.D. (2000) 'A theoretical extension of the technology acceptance model: four longitudinal field studies', Management Science, Vol. 46, No. 2, pp.186-204.

Webster, J. and Trevino, L.K. (1995) 'Rational and social theories as complementary explanations of communication media choices: two policy-capturing studies', Academy of Management Journal, Vol. 38, No. 6, pp.1544-1573.

Wu, J. and Wang, S. (2005) 'What drives mobile commerce? An empirical evaluation of the revised technology acceptance model', Information and Management, Vol. 42, No. 5, pp.719-729. 


\section{Appendix}

\section{Survey instrument}

Dear respondent,

This survey asks you about your attitudes and behaviours related to using social media for sales in your work practice. Your answers will be used for a university research study and the information you provide will be completely confidential, with only aggregated data used in the final report. Your participation is voluntary. At the end of the survey you will receive a link to an email address and a unique completion code. Please e-mail this code to receive a copy of the survey results. By selecting 'I agree' below, you are agreeing to participate in this study.

O I agree

O I disagree

What is your primary business?

a. Consumer brand manufacturer

$\mathrm{O}$ b. B2B manufacturer

c. Distributor

O d. Retailer

e. Consumer service provider

f. Business service provider

g. Other

What social media do you employ for work? Please select all that apply.

a. Facebook

b. Twitter

c. YouTube

a d. LinkedIn

e. Community on your company's website

f. I do not use social media for work

g. Other 
What social media do you participate in for personal reasons? Please select all that apply.

$\square$ a. Facebook

口 b. Twitter

$\square$ c. YouTube

$\square$ d. LinkedIn

$\square$ e. Community on your company's website

f. I do not use social media for personal purposes

다ick to write Choice 8

$\square$ g. Other

What are the benefits social media may provide for your business? Please select all that apply.

$\square$ a. Increase awareness of you and/or your company

$\square$ b. Spread your sales message

$\square$ c. Prospect new customers

- d. Maintain communication and relationships with existing customers

e. Enable customers to participate in product/service development

f. Enable customers to participate in market research

g. Provide customer feedback

$\square$ h. Improve customer support/customer service

$\square$ i. Other

What social media tactics work best for you? Please select all that apply.

$\square$ a. Creating my own account on a social network site and inviting followers

$\square$ b. Creating a brand community/customer forum on my own site

c. Using a social media site to develop and/or expand professional network

a d. Placing advertising on social media sites

e. Offering discounts and specials to friends and followers

f. Engaging customers in discussions, contests and other activities

$\square$ g. Providing customer support and advice

$\square$ h. Other 
What percent of your new clients come from social media use?

a. $1 \%$ to $5 \%$

b. $5.1 \%$ to $10 \%$

O c. $10.1 \%$ to $25 \%$

O d. More than $25 \%$

O e. N/A

What percent of your current clients interact with you on social media sites?

a. $1 \%$ to $5 \%$

○. b. $5.1 \%$ to $10 \%$

c. $10.1 \%$ to $25 \%$

O d. More than $25 \%$

O e. N/A

When did you first start using social media marketing? (For those who do not use it, when did you first learn about social media marketing?)

a. Less than 1 year ago

b. Between 1 and 2 years ago

c. Between 2 and 3 years ago

d. Between 3 and 5 years ago

e. More than 5 years ago

What are the reasons you use (or would consider using) social media marketing? Select. Please select all that apply.

a. To reduce sales/communication expenses

$\square$ b. To be an early player in the social media medium

c. Because everybody else is using it/not to appear a technology laggard

d. To provide enhanced communication with existing clients

e. To better reach potential clients

f. To try a new approach

g. Other 
Please indicate whether you agree or disagree with the following statements

\begin{tabular}{|c|c|c|c|c|c|c|c|}
\hline & $\begin{array}{l}\text { Strongly } \\
\text { disagree }\end{array}$ & & & & & & $\begin{array}{c}\text { Strongly } \\
\text { Agree }\end{array}$ \\
\hline Using social media marketing improves my job performance & $\mathrm{O}$ & $\mathrm{O}$ & O & O & $\mathrm{OC}$ & O & $\mathrm{O}$ \\
\hline $\begin{array}{l}\text { Using social media marketing in my job increases my } \\
\text { productivity }\end{array}$ & O & $\mathrm{O}$ & O & $\mathrm{O}$ & $\mathrm{OC}$ & O & O \\
\hline $\begin{array}{l}\text { Using social media marketing enhances my effectiveness in } \\
\text { my job }\end{array}$ & $\mathrm{O}$ & $\mathrm{O}$ & $\mathrm{O}$ & $\mathrm{O}$ & $\mathrm{OC}$ & $\mathrm{O}$ & $\mathrm{O}$ \\
\hline I find social media marketing useful in my job & $\mathrm{O}$ & $\mathrm{O}$ & $\mathrm{O}$ & $\mathrm{O}$ & $\mathrm{OC}$ & O & $\mathrm{O}$ \\
\hline I find social media easy to use for sales & $\mathrm{O}$ & $\mathrm{O}$ & $\mathrm{O}$ & $\mathrm{O}$ & $\mathrm{OC}$ & O & $\mathrm{O}$ \\
\hline I find it easy to get social media to do what I want it to do & $\mathrm{O}$ & $\mathrm{O}$ & $\mathrm{O}$ & $\mathrm{O}$ & $\mathrm{OC}$ & O & O \\
\hline $\begin{array}{l}\text { My interaction with social media marketing is clear and } \\
\text { understandable }\end{array}$ & $\mathrm{O}$ & $\mathrm{O}$ & $\mathrm{O}$ & O & $\mathrm{OC}$ & O & O \\
\hline $\begin{array}{l}\text { Using social media for sales does not require a lot of my } \\
\text { mental effort }\end{array}$ & $\mathrm{O}$ & $\mathrm{O}$ & $\mathrm{O}$ & $\mathrm{O}$ & $\mathrm{OC}$ & O & O \\
\hline $\begin{array}{l}\text { The majority of my sales colleagues in my firm use social } \\
\text { media marketing tools }\end{array}$ & $\mathrm{O}$ & $\mathrm{O}$ & $\mathrm{O}$ & $\mathrm{O}$ & $\mathrm{OC}$ & $\mathrm{O}$ & $\mathrm{O}$ \\
\hline $\begin{array}{l}\text { In my sales organisation social media marketing is heavily } \\
\text { employed by everyone }\end{array}$ & $\mathrm{O}$ & $\mathrm{O}$ & $\mathrm{O}$ & O & $\mathrm{OC}$ & $\mathrm{O}$ & $\mathrm{O}$ \\
\hline $\begin{array}{l}\text { A lot of my sales colleagues rely on social media marketing } \\
\text { for work }\end{array}$ & $\mathrm{O}$ & O & $\mathrm{O}$ & 0 & 0 & O & 0 \\
\hline $\begin{array}{l}\text { Our competitors' sales reps use social media marketing } \\
\text { extensively }\end{array}$ & 0 & 0 & 0 & $\mathrm{O}$ & $O$ & O & 0 \\
\hline $\begin{array}{l}\text { Our competitors' sales forces are equipped with up-to-date } \\
\text { social media marketing tools }\end{array}$ & 0 & 0 & 0 & 0 & 0 & 0 & 0 \\
\hline $\begin{array}{l}\text { Competing sales executives use a lot of social media } \\
\text { marketing }\end{array}$ & 0 & 0 & 0 & 0 & 0 & O & 0 \\
\hline $\begin{array}{l}\text { Our competitors' salespeople rely on social media in dealing } \\
\text { with their customers }\end{array}$ & 0 & 0 & 0 & 0 & $O$ & O & O \\
\hline $\begin{array}{l}\text { My customers show great interest when I use social media } \\
\text { marketing }\end{array}$ & 0 & 0 & 0 & 0 & $O$ & 0 & 0 \\
\hline $\begin{array}{l}\text { Many of my customers like it when I rely upon social media } \\
\text { marketing }\end{array}$ & 0 & 0 & 0 & 0 & 0 & 0 & 0 \\
\hline $\begin{array}{l}\text { The fact that I use social media marketing is very appealing } \\
\text { to my customers }\end{array}$ & 0 & 0 & $\mathrm{O}$ & 0 & $O$ & O & 0 \\
\hline My customers expect me to use social media marketing & O & O & $\mathrm{O}$ & $\mathrm{O}$ & $\mathrm{OC}$ & O & $\mathrm{O}$ \\
\hline $\begin{array}{l}\text { I am continuously encouraged by my immediate supervisor } \\
\text { to use social media in my job }\end{array}$ & $\mathrm{O}$ & O & O & $\mathrm{O}$ & $\mathrm{OC}$ & O & $\mathrm{O}$ \\
\hline $\begin{array}{l}\text { My immediate supervisor explicitly supports my using social } \\
\text { media for sales }\end{array}$ & $\mathrm{O}$ & O & $\mathrm{O}$ & $\mathrm{O}$ & $\mathrm{OC}$ & O & O \\
\hline $\begin{array}{l}\text { My immediate supervisor truly believes in the benefits of } \\
\text { social media for sales }\end{array}$ & $\mathrm{O}$ & O & $\mathrm{O}$ & $\mathrm{O}$ & $\mathrm{OC}$ & O & $\mathrm{O}$ \\
\hline
\end{tabular}


Please agree or disagree with the following statements

\begin{tabular}{lcccccccc}
\hline & $\begin{array}{c}\text { Strongly } \\
\text { disagree }\end{array}$ & & $\begin{array}{c}\text { Strongly } \\
\text { agree }\end{array}$ \\
\hline $\begin{array}{l}\text { I tend to be among the first to use new selling tools } \\
\begin{array}{l}\text { Among my peers I am usually among the first to explore } \\
\text { new selling tools }\end{array}\end{array}$ & 0 & 0 & 0 & 0 & 0 & 0 & 0 & 0 \\
$\begin{array}{l}\text { I am receptive to new selling tools } \\
\begin{array}{l}\text { I consider myself a frequent user of social media marketing } \\
\text { for my sales work }\end{array}\end{array}$ & 0 & 0 & 0 & 0 & 0 & 0 & 0 \\
$\begin{array}{l}\text { I have completely integrated social media into my sales } \\
\text { process }\end{array}$ & 0 & 0 & 0 & 0 & 0 & 0 & 0 \\
I fully use the capabilities of social media in my sales work & 0 & 0 & 0 & 0 & 0 & 0 & 0 \\
I intend to use social media marketing on a regular basis & 0 & 0 & 0 & 0 & 0 & 0 & 0 \\
\hline
\end{tabular}

Overall, how would you describe (would envision) your experience with social media marketing?

\begin{tabular}{lccccccc}
\hline & 1 & 2 & 3 & 4 & 5 & 6 & 7 \\
\hline Bad:Good & $\mathrm{O}$ & $\mathrm{O}$ & $\mathrm{O}$ & $\mathrm{O}$ & $\mathrm{O}$ & $\mathrm{O}$ & $\mathrm{O}$ \\
Unfavourable:Favourable & $\mathrm{O}$ & $\mathrm{O}$ & $\mathrm{O}$ & $\mathrm{O}$ & $\mathrm{O}$ & $\mathrm{O}$ & $\mathrm{O}$ \\
Unpleasant:Pleasant & $\mathrm{O}$ & $\mathrm{O}$ & $\mathrm{O}$ & $\mathrm{O}$ & $\mathrm{O}$ & 0 & 0 \\
Negative:Positive & $\mathrm{O}$ & $\mathrm{O}$ & $\mathrm{O}$ & $\mathrm{O}$ & $\mathrm{O}$ & $\mathrm{O}$ & $\mathrm{O}$ \\
\hline
\end{tabular}

What is the probability you will use (continue to use) social media marketing in the future?

\begin{tabular}{|c|c|c|c|c|c|c|c|}
\hline & 1 & 2 & 3 & 4 & 5 & 6 & 7 \\
\hline Unlikely:Likely & $\mathrm{O}$ & $\mathrm{O}$ & $\mathrm{O}$ & O & $\mathrm{O}$ & $\mathrm{O}$ & $\mathrm{O}$ \\
\hline Imporbable:Probable & $\mathrm{O}$ & $\mathrm{O}$ & O & $\mathrm{O}$ & $\mathrm{O}$ & $\mathrm{O}$ & $\mathrm{O}$ \\
\hline Impossible:Possible & $\mathrm{O}$ & $\mathrm{O}$ & $\mathrm{O}$ & $\mathrm{O}$ & $\mathrm{O}$ & $\mathrm{O}$ & 0 \\
\hline
\end{tabular}

What is your position within the company?
a. Salesperson
b b. Sales manager
c. Other 
OPTIONAL Please Indicate the URLs for your social media accounts. This information will not be used to identify you within the survey context or be shared with anyone beyond one primary researcher, but we will use it to collect objective measures of your use of social media marketing tools:

a a. Facebook

$\square$ b. Twitter

$\square$ c. LinkedIn

$\square$ d. Youtube

$\square$ e. Other

What is your annual quota or target sales revenue?

What percentage of quota target do you expect to hit this year?

O $<80 \%$

○ $81 \%-100 \%$

O $100 \%-\mathrm{DO} \%$

O $\mathrm{DO} \%$

What is your company's annual revenue?

O Below $\$ 5$ million

○ $\$ 5$ million to $\$ 10$ million

O $\$ 10$ million to $\$ 25$ million

O $\$ 25$ million to $\$ 50$ million

O More than $\$ 50$ million 